\title{
ПРОГРАМА ВДОСКОНАЛЕННЯ ВИКЛАДАННЯ У ВИЩІЙ ОСВІТІ (НАВЧАННЯ ВИКЛАДАЧІВ) - ТРЕТІЙ ЕТАП НАВЧАННЯ
}

https://doi.org/10.37472/2707-305X-2020-2-2-4-2

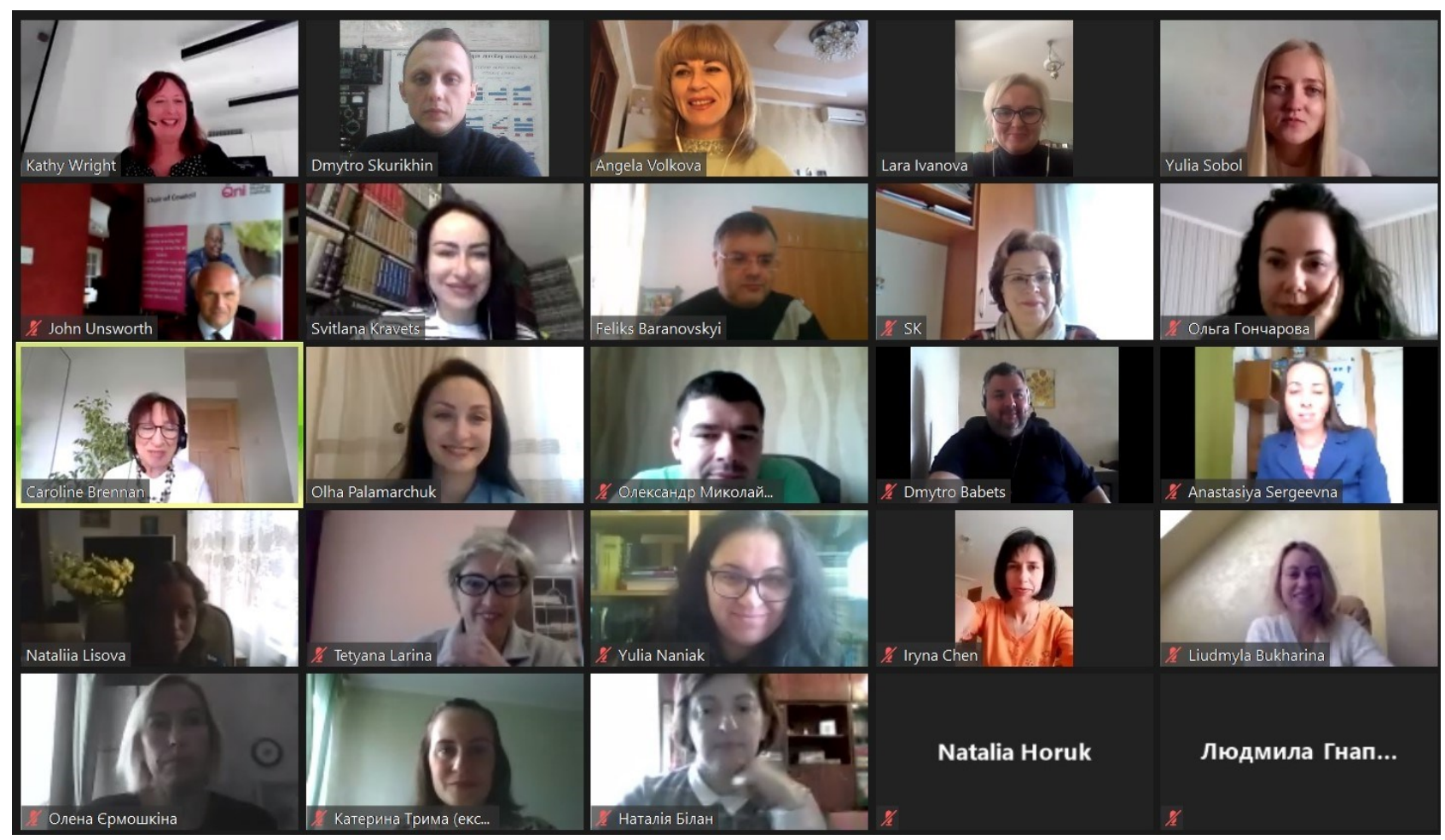

\section{КАЛАШНІКОВА}

Світлана Андріївна доктор педагогічних наук, профресор, членкореспондент НАПН України, директор Інституту вищої освіти Національної академії педагогічних наук України, м. Київ, Україна (iD)
Анотація. Представлено третій етап виконання у жовтні 2020 р. Програми вдосконалення викладання у вищій освіті, що реалізується Інститутом вищої освіти НАПН України за участі тренерів британської агенції Advance HE, а також за підтримки Британської Ради в Україні, МОН України і Нацагенства забезпечення якості вищої освіти. Учасниками Програми були науковопедагогічні працівники десяти університетів України. Онлайн сесії базувалися на інтенсивній підготовчій діяльності учасників Програми з матеріалами та завданнями, розміщеними у навчальному середовищі Brightspace.

Ключові слова: інституційна спроможність; якість вищої освіти; вдосконалення викладання; професійний розвиток.

19, 20, 29 та 30 жовтня 2020 р. відбулася серія вебінарів, які для учасників Програми вдосконалення викладання у вищій освіті (далі - Програма) провели тренери британської агенції Advance HE.

Тематика вебінарів:

- Дизайн / розроблення освітньої програми - ключові концепції.

- Дизайн / розроблення навчальної дисципліни - ключові концепції.

- Активне планування та моделювання змін.

- Креативні підходи до навчання та викладання.

- Педагогічні підходи, що забезпечують значний вплив - симуляції, проблемно-орієнтоване навчання (навчання на основі кейсів), геймификація. 


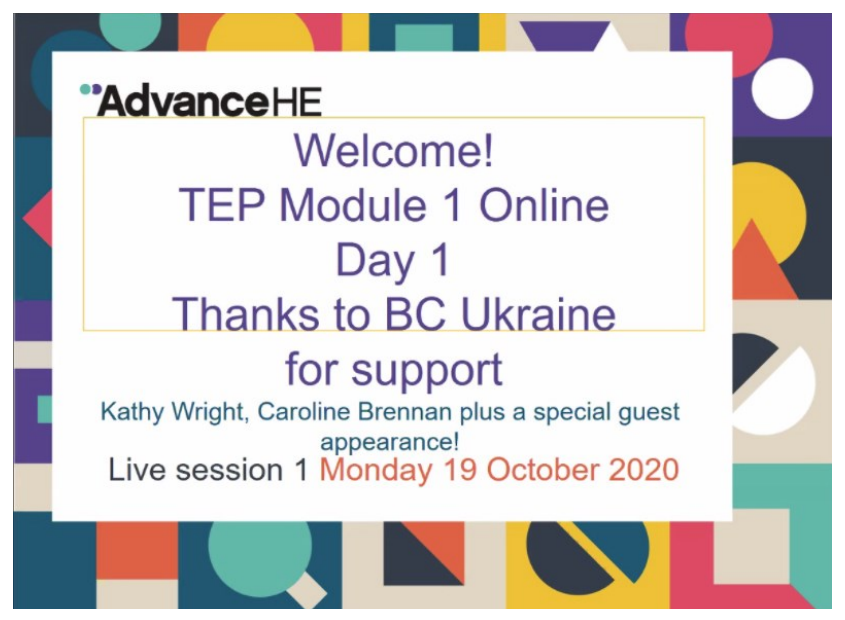

- Ефективне викладання та навчання онлайн: інновації та вплив.

Учасниками Програми є викладачі десяти університетів України:

- Запорізький національний університет;

- Київський національний університет імені Тараса Шевченка;

- Львівський національний університет імені Івана Франка;

- Мелітопольський державний педагогічний університет імені Богдана Хмельницького;

- Національний університет «Острозька академія»;

- Ніжинський державний університет імені Миколи Гоголя;

- Національний технічний університет «Дніпровська політехніка»;

- Сумський державний університет;

- Тернопільський національний педагогічний університет імені Володимира Гнатюка;

- Український державний університет залізничного транспорту.

Онлайн сесії базувалися на інтенсивній підготовчій діяльності учасників Програми з матеріалами та завданнями, розміщеними у навчальному середовищі Brightspace.

\begin{tabular}{|c|c|c|c|}
\hline Assessment Tools & Knowledge Tools & Community Tools & $\begin{array}{l}\text { Learner Centred } \\
\text { Tools }\end{array}$ \\
\hline $\begin{array}{l}\text { Voting tools: (Poll } \\
\text { Everywhere/ } \\
\text { Mentimeter) }\end{array}$ & $\begin{array}{l}\text { VLEs: } \\
\text { Brightspace/Moodle }\end{array}$ & $\begin{array}{l}\text { Zoom/MS Teams Live } \\
\text { sessions }\end{array}$ & $\begin{array}{l}\text { Google tools: } \\
\text { jamboards/sites }\end{array}$ \\
\hline Kahoot & $\begin{array}{l}\text { Screencasts/Podcast } \\
\text { s/Lecture capture }\end{array}$ & Instagram/Facebook & Blogs \\
\hline Answergarden & YouTube & Snapchat/WhatsApp & Microblogging: Twitter \\
\hline EdPuzzle & Coursera & Padlet & $\begin{array}{l}\text { Infographics: } \\
\text { Piktochart }\end{array}$ \\
\hline Socrative & Khan Academy & Flipgrid & Wikis (pbworks) \\
\hline Google Forms & PhET Simulations & Wakelet & Adobe Spark \\
\hline Wordwall & Mindmeister & Hypothes is & Canva \\
\hline Kialo.com & Quizlet & Sketchboard.io & Thinglink \\
\hline
\end{tabular}

\section{Good learning outcomes are}

+ Active - it describes what students can do

+ Attractive - students want to achieve it

+ Comprehensible - students know what it means

+ Appropriate - to the student's current goals and career plans

+ Attainable - most students will mostly meet it, with due effort

+ Assessable - we can see if it has been achieved

+ Visible - in the course booklet and on the VLE

Загальна інформачія про Програму

Програма вдосконалення викладання у вищій освіті реалізується Інститутом вищої освіти Національної академії педагогічних наук України у партнерстві з Британською Радою в Україні, за участі британської агенції Advance $\mathrm{HE}$ та за підтримки Міністерства освіти і науки України та Національного агентства забезпечення якості вищої освіти.

Мета Програми - підвищення якості вищої освіти України шляхом розвитку інституційної спроможності університетів України щодо вдосконалення викладання і навчання.

Протягом трьох років (2019-2021 рр.) до участі у Програмі планується залучити 30 університетів України.

у межах реалізації Програми передбачено здійснення низки ініціатив, спрямованих на підсилення інституційної спроможності закладів вищої освіти України щодо вдосконалення викладання, зокрема:

- навчання викладачів університетів;

- професійний розвиток представників керівного складу закладів вищої освіти;

- розроблення та реалізація інституційних проектів університетів;

- розроблення Національної електронної платформи «Вища освіта України: кращі практики»;

- підготовка та видання посібника для викладачів університетів та онлайн курсу для молодих викладачів та ін.

\section{СПИСОК ВИКОРИСТАНИХ ДЖЕРЕЛ}

Advance HE. (n.d.). Home. https://www.advance-he.ac.uk/ Інститут вищої освіти НАПН України. (2020, 12 листопада). Програма вдосконалення викладання у вищій освіті (навчання викладачів) - mpemiŭ етап навчання. https://cutt.ly/UhjveuC

Інститут вищої освіти НАПН України. (2019, 9 грудня). Проєкт «Програма вдосконалення викладання у вищій освіті» (2019-2021 роки). https://ihed.org.ua/ internationalization/tehe_ukraine/

Калашнікова, С.А. (2020). Програма вдосконалення викладання у вищій освіті: перший цикл. Вісник Національної академії педагогічних наук України, 2(1). https://doi.org/10.37472/2707-305X-2020-2-1-4-3 


\section{UKRAINE HIGHER EDUCATION TEACHING EXCELLENCE PROGRAMME (ACADEMIC STAFF TRAINING): THE THIRD STAGE OF TRAINING}

Svitlana Kalashnikova

DSc in Education, Professor, Corresponding Member of NAES of Ukraine, Director, Institute of Higher Education of the National Academy of Educational Sciences of Ukraine, Kyiv, Ukraine

Abstract. The third stage of the Ukraine Higher Education Teaching Excellence Programme is presented, which was held in October 2020. The Programme is realized by the Institute of Higher Education of the National Academy of Educational Sciences of Ukraine in partnership with the British Council in Ukraine, Advance HE (UK) and with support of the Ministry of Higher Education and Science of Ukraine and National Agency for Higher Education Quality Assurance. The Programme participants were the academic staff of ten Ukrainian universities. The online sessions were based on the participants' intensive preparatory activity on the materials and tasks placed at the Brightspace learning environment.

Keywords: institutional capacity; higher education quality; teaching excellence; professional development.

Дата публікації: 27 листопада 2020 р. 